\title{
Value Chain Analysis of Kocho: The Case of Cheha and Mirab Azernet Districts
}

\author{
Destaw Muluye \\ Agricultural Economics Researchers, Worabe Agricultural Research Center, Worabe, Ethiopia
}

The research is financed by South agricultural research institute (SARI)

\begin{abstract}
Enset based farming system is an important staple crop for million people living in the densely populated regions of South and Southwestern Ethiopia. However, only restricted intervention has been done to upgrade the crop even the consumption demand increases from time to time in different part of the country. This research attempted to analyze value chain of enset product in Cheha and Mirab Azernet districts, SNNPR of Ethiopia focusing on kocho product. Since, kocho plays a significant role in increasing food security and income for the poor farmers in the study districts. Data for the study were collected from both primary and secondary data sources. The data were collected from 154 farmers, 35 traders and 28 consumers. The study result revealed that the production of kocho from enset crop were used more for consumption while the rest was marketed. In addition, interview and observation results also showed that the production of kocho declined because of enset disease that destroyed the crop, absences of institutional and technological enhancements were accredited to existing inefficiencies in enset production and utilization. kocho value chain actors identified in the study include input suppliers, producers, local collectors, retailers, wholesalers, individual processors and consumers. Five market channels were identified for kocho. The highest total gross marketing margin was $33.53 \%$ in channel III. The highest gross marketing margin of smallholder farmers in kocho was $80 \%$ in channel II. The result of two stage double hurdle model revealed that, out of total 12 explanatory variables included in the model. kocho market participation decision was significantly affected by quantity of kocho produced, enset production experience, market information, credit access. Quantity of kocho produced, distance to nearest market center, marketing experience and average kocho market price significantly affected the volume of kocho supplied to the market. Policy suggestions drawn from the study results include the need to improve the input access system, improving farmers' knowledge and experience on enset production, solidification extension services for enset production and marketing, strengthening the linkage among enset products value chain actors, improve enset diseases controlling mechanisms, needs attention on enset harvesting and processing technologies and strengthening supportive institutions.
\end{abstract}

Keywords: Enset; Kocho; Value chain; Double-hurdle model; Cheha, Mirab Azernet.

DOI: $10.7176 / \mathrm{IKM} / 12-1-03$

Publication date: January $31^{\text {st }} 2022$

\section{INTRODUCTION}

\subsection{Background and Justification of the Study}

Enset based farming system is an important staple crop for more than 20 million people living in the densely populated regions of South and Southwestern Ethiopia (Borrell et al., 2019). The crop is being grown in many regions, however the dwellers of the central and southwestern parts of Ethiopia are the only people who usually used its products as a staple and co-staple food (Awiersum and Bongers, 2010).

Enset is perceived to be relatively tolerant of drought, withstand heavy rain, tolerate flooding, and endure frost damage (Belachew et al., 2017; Zerfu et al., 2018). Enset can be harvested at any time during the year at any growth stage and the fermented enset products can be stored for long periods, basis of many households' food security (Brandt et al., 1997; Belachew et al., 2017; Sahle et al., 2018). Enset is multipurpose crop used for food, fodder, fibers, traditional medicines, construction, ornamental purpose, fuel wood, containers, and as a provider of shade to intercropped annual or perennial crops (Olango et al., 2014). The main food products obtained from enset plant are kocho, bulla and amicho (Brandt et al., 1997; Ashenafi et al., 2017).

Enset products are core sources of food and income, its production is vital in Ethiopia. Yet, this vast potential of production has not fully exploited and promoted in the country. Weak marketing infrastructure, use of traditional technologies, limited supply, and poor marketing support services and market information contribute to under manipulation of enset production potential. Moreover, land shortage, persistent drought, disease, lack of improved varieties in terms of yield and disease resistance; labor shortage, lack of improved processing and storage technologies, improper or cultural agronomic practice, financial limitation and longtime maturity are the main challenge in enset production. Besides, weak collaboration among and between value chain actors, inefficient enset marketing characterized by high margins and poor marketing infrastructure and services is considered to be a main constraint enset product marketing (Ashenafi et al., 2017, Shumbulo et al., 2012, Yilma, 2001).

In the previous, most of interventions to develop Enset farm focused more on increasing production food contribution, gender analysis, bio-diversity and livelihood activity and with less attention to marketing system and 
value chain. However, the development of improved marketing system and linkages among actors are key to increase production (Abebe and Paul, 2015). Production, processing, marketing and consumption activities are not organized to generate competitiveness and efficiency, subjected to periodical variation where surplus supply at the harvest time is the main feature (Haile et al., 2020; Nuri et al., 2016).

Enset is importance in improving welfare of farmers through household income, food security, poverty reduction and promotion of nutritional status in the study areas. However, use of traditional technologies and weak linkages along the market chain were mentioned the major problems constraining the potential benefits from the crop farming, limited empirical research evidences on its production, marketing and development practice of the crop to address the existing challenges in the study areas. Enset products actors' role, share of benefit and marketing margins along the value chain were not distinguished. Likewise, factors affecting market participation decision and market supply were not identified in the study areas. Hence, this study was intended to investigate value chain analysis of kocho product at Cheha and Mirab Azernet districts and achieved the following objectives: (a) to identify kocho product value chain marketing channels, actors and to draw up value chain map in the study area; (b) to analyze respective marketing margins across market channels in the study areas; (c) to identify factors affecting kocho product market participation decision and market supply; (d) to identify major opportunities and constraints of kocho value chain in the areas.

\section{RESEARCH METHODOLOGY}

\subsection{Description of the Study Area}

This study was undertaken in Cheha and Mirab Azernet districts of Gurage and Siltie Zones, respectively, Southern Nations, Nationalities and Peoples Regional State, Ethiopia.

\subsubsection{Cheha district}

Cheha district is one of the districts in Gurage zone, SNNPR, Ethiopia. The capital of the district is Emdbir, which is located at $188 \mathrm{~km}$ south - west of Addis Ababa on the way to Wolkite to Hossana town. The geographical location of the district extends from $8^{\circ} 00^{\prime} 18.9^{\prime \prime}$ to $8^{\circ} 15^{\prime} 28.53^{\prime \prime} \mathrm{N}$ and $37^{\circ} 35^{\prime} 46.48^{\prime \prime}$ to $38^{\circ} 03^{\prime} 59.59^{\prime \prime} \mathrm{E}$ at an elevation ranging from 1,900 to 3,000 meters above sea level (masl). Cheha district is bordered on the south by Enemorina Eaner, on the west by the Oromia Region, on the north by the Wabe river which separates it from Abeshge and Kebena, on the east by Ezha, and on the southeast by Gumer and Geta districts. The district constitutes 39 rural kebeles. The average annual rainfall of the area is about $1268.04 \mathrm{~mm}$. The existence agriculture in Cheha district is primarily based on enset, teff, maize, wheat, sorghum, potato, faba bean, field pea crop types. Farmers of the district also widely produce enset for different purposes like for food in the form of kocho, bulla, and amicho, for medical purpose and for construction. The leaves of enset are also used for different purposes like fed for cattle, tie and cooking of bread (CDOoA, 2020).

\section{Mirab Azernet district}

Mirab Azernet district is one of the districts in Siltie zone, SNNPR, Ethiopia. The capital of the district is Lera located $250 \mathrm{~km}$ south-west of Addis Ababa. Mirab Azernet is bordered on the southwest by the Hadiya zone, on the northwest by the Gurage zone, and on the east by Misraq Azernet Berbere district. It has two different agro climatic conditions, Dega and Woina-dega and consisting $37 \%$ and $63 \%$, respectively. The average annual rainfall ranges from $1200 \mathrm{~mm}$. Crop production takes the lion's share of consumption and income generation of the households. Cereals crops widely produced in the area include barley, wheat, pulse crops like field pea and faba beans, tuber and root crops include enset, potato, cabbage are major crops grown in the district. Particularly enset is main crop type using by farmers for different purpose (MADOoA, 2020).

\subsection{Research Design, Data Types, Sources and Sampling Procedures}

\subsubsection{Data types and sources}

Both qualitative and quantitative data types were collected from primary and secondary data sources. The primary data was collected directly from sampled households. Secondary data sources used for this study were journals, relevant text books, Cheha and Mirab Azernet district agricultural and marketing office reports.

\subsubsection{Sampling procedure}

For this particular study Cheha and Mirab Azernet districts were selected purposively based on the enset production potential and marketing practice. The sample for this study was drawn from all actors involved along kocho value chain such as producers, local collectors, wholesalers, retailers, processors and consumers. Then this study was applied multi-stage sampling procedure to identify the sample households for data collection from enset producer kebeles in districts. In first stage, cluster sampling technique was used based on enset production potentials of the kebeles. Each district was clustered in to two clusters such as high enset producer, medium enset producer kebeles. In second stage, out of enset producer kebeles in districts, four kebeles were selected by using simple random sampling technique (two kebeles from medium enset producer kebeles and two kebeles from high enset producer kebeles). In last stage, the sample respondents were selected by using systematic random sampling technique in each kebele. Finally, a total of 154 sample households were selected from the two districts for the 
purpose of this study.

\subsubsection{Sample size determination}

This study was applied a simplified formula provided by (Yamane, 1967). Accordingly, the required sample size at $95 \%$ confidence level with degree of variability of $5 \%$ and level of precision equal to $8 \%$ are used to obtain a sample size required which represent a true population.

$$
\mathrm{n}=\frac{\mathrm{N}}{1+\mathrm{N}\left(e^{2}\right)} \quad \mathrm{n}=\frac{13,254}{1+13,254\left(0.08^{2}\right)} \quad=154
$$

Where, $\mathrm{n}=$ sample size, $\mathrm{N}=$ population size (sampling frame) and $\mathrm{e}=$ level of precision considered $8 \%$

Table 1: The distribution of sample households across sample kebeles.

\begin{tabular}{llcc}
\hline District & Sample kebeles & Number of enset growers & Sample households \\
\hline Cheha & Dakona & 500 & 42 \\
& Moche & 445 & 38 \\
Mirab Azernet & Jaremo & 465 & 40 \\
& Kecha chumeta & 398 & 34 \\
& Total & 1808 & 154 \\
\hline
\end{tabular}

Source: District and kebele offices, 2020

The sites for the trader surveys were different market places in which a good sample of enset products traders existed. On the basis of flow of enset products, four markets (Emdbir, Lera, Bole and Wolkitie) were selected as, the major enset products marketing sites for this study. Due to absence of recorded list of population of traders a purposive sampling method was used to select wholesalers, rural collectors and retailers from specified markets. As a result, 35 kocho and bulla traders were selected for the purpose of this study. Furthermore, 1 processor and 28 consumers were interviewed.

\subsection{Methods of Data Collection}

Different methods of data collection tools were implemented to acquire primary data. Among the data collection tools key informant interview and focus group discussion with pre-defined social groups (elders, model farmers, women's, Das and experts) were conducted before formal survey to collect general information about the study area enset production and marketing. A checklist was also used to guide the discussion conducted to generate data that cannot be collected from individual interviews. The required households' data were collected from selected sample households with the help of pre - tested structured questionnaires.

\subsection{Method of Data Analysis}

Both descriptive and econometric data analysis methods were applied to analyze the data collected from smallholder respondents using structured questionnaire. The analysis was done through using SPSS version 25 and STATA 15.

\subsubsection{Value chain analysis}

Value chain analysis is the process of breaking a chain into its constituent parts in order to better understand its structure and functioning. To understand the characteristics of the chain actors of enset products and the relationships exists between them, including the identification of all actors in the chain; the flow of product via the chain; the work features and the destination; information was obtained by conducting interviews, focus group discussion and by collecting secondary data from various sources. The study has employed value chain analysis which is very effective in tracing product flows, showing the physical value adding stages, qualitative and quantitative flow of product along the chain with identified key actors, their relationships with other actors in the chain and measured distribution of their benefits. This could be captured through mapping the value chain.

\subsubsection{Marketing margin}

According to Ghorbani (2008), marketing margin is important directories in the evaluation of value chain performance. It is the difference in the price paid by consumers and that received by the producers. Marketing margins are also calculated at different points along the value chain and then compared with consumer price. Once the basic structure of a marketing channel is established, it is relatively easy to collect information on the price at which the product is bought and sold at each stage in the production process (Smith, 1992). Computing the total gross marketing margin (TGMM) is always related to the final price paid by the end buyer and is expressed as percentage (Mendoza, 1995).

$$
\begin{aligned}
& T G M M=\frac{\text { Final consumers price }- \text { Producers price }}{\text { Final consumers price }} * 100 \\
& \text { Where, TGMM is total gross marketing margin } \\
& \text { GMMp }=\frac{\text { Final consumers price-Marketing gross margin }}{\text { Final consumers price }} * 100 \quad \text { Or }
\end{aligned}
$$


$\mathrm{GMM}_{\mathrm{P}}=1-\mathrm{TGMM}$

Where, $\mathrm{GMM}_{\mathrm{p}}$ is the producers share in final consumer price

GMMt $=\frac{\text { Selling price }- \text { Purchasing price }}{\text { Final consumers price }} * 100$

Where, $\mathrm{GMM}_{\mathrm{t}}$ is the traders share in final consumer price

$$
\mathrm{NMM}=\frac{\text { Marketing gross margin }- \text { marketing costs }}{\text { Final consumers price }} * 100
$$

The net marketing margin (NMM) is the percentage of the final price earned by the intermediaries as their net income after their marketing costs are deducted.

\subsubsection{Econometric model specification}

A double hurdle model was used to identify the factors that determine smallholder farmers' decision to participate (or not) in the output markets and the quantity of their supplied to the market. The determinants of decision to market participation kocho were analyzed first and then the determinants of quantity of supplied to the market was followed. Double hurdle model (Cragg, 1971) involves two-step estimation procedure.

First stage: In the first stage, probit model (first hurdle estimation) was used to identify factors affecting decision to market participation. Probit model takes values 1 and 0 that were assigned to represent the choice whether a farmer decides to participate kocho market or not.

$\mathrm{Y}_{\mathrm{i}}^{*}=\mathrm{x}_{\mathrm{i}} \beta+\mathrm{e}_{\mathrm{i}}$

$\mathrm{Y}_{\mathrm{i}}=\left\{\begin{array}{l}1 \text { if } \mathrm{Yi} *>0 \\ 0 \text { if } \mathrm{Yi} * \leq 0\end{array}\right\}$

Where $\mathrm{Y}_{\mathrm{i}}^{*}$ is the probability of an individual farm household decision to participate in kocho and bulla marketing; $\beta_{i}$ is the vector of parameters to be estimated; $X_{i}$ is the vector of explanatory variables explaining the participation decision probability; $e_{i}$ is the error term and the error terms are assumed to be independently ei $\sim \mathrm{N}(0,1)(\mathrm{Carol}$ et al., 2003).

Second stage: In the second stage, the truncated regression (second hurdle estimation) model was used to analyze factors determining the quantity of kocho supplied to the market. Truncated regression excludes part of sample observation based on the value of the dependent variable. That is, the truncated regression uses observations only from sample households whose quantity supplied to the market positive or greater than zero. The quantity of kocho and bulla supplied to the market is modeled as a regression truncated at zero:

$$
\begin{aligned}
& \mathrm{Q}_{\mathrm{i}}^{*}=\mathrm{x}_{\mathrm{i}} \beta+\mu_{\mathrm{i}}, \mu_{\mathrm{i}} \sim \mathrm{N}\left(0, \sigma^{2}\right) \\
& \mathrm{Q}_{\mathrm{i}}=\left\{\begin{array}{c}
1 i f \mathrm{Qi} *>0 \text { or } Y i=1 \\
0 \text { otherwise }
\end{array}\right\}
\end{aligned}
$$

Where Qi is the intensification quantity of marketed which depends on latent variable Qi* being greater than zero and conditional to the decision to participate in kocho marketing Yi. If both decisions are made by the individual producers independently, the error terms are assumed to be normally distributed as: $\sim N\left(0, \sigma^{2}\right)($ Carol et al., 2003).

\section{RESULTS AND DISCUSSION}

\subsection{Value Chain Map of Enset Product (Kocho) in the Study Districts}

Value chain mapping enables to picture the flow of the product from input supply to end consumer through various actors. It helps to identify the different actors involved in the value chain, activities performance and to understand their roles and linkages. Therefore, understanding of value chain for enset products is paramount important to examine factor that affecting smallholder farmers to meet market requirement and demand conditions through improving competitive and efficiency. Main activities include in enset products mapping input supply, production, trading, processing and consumption. 


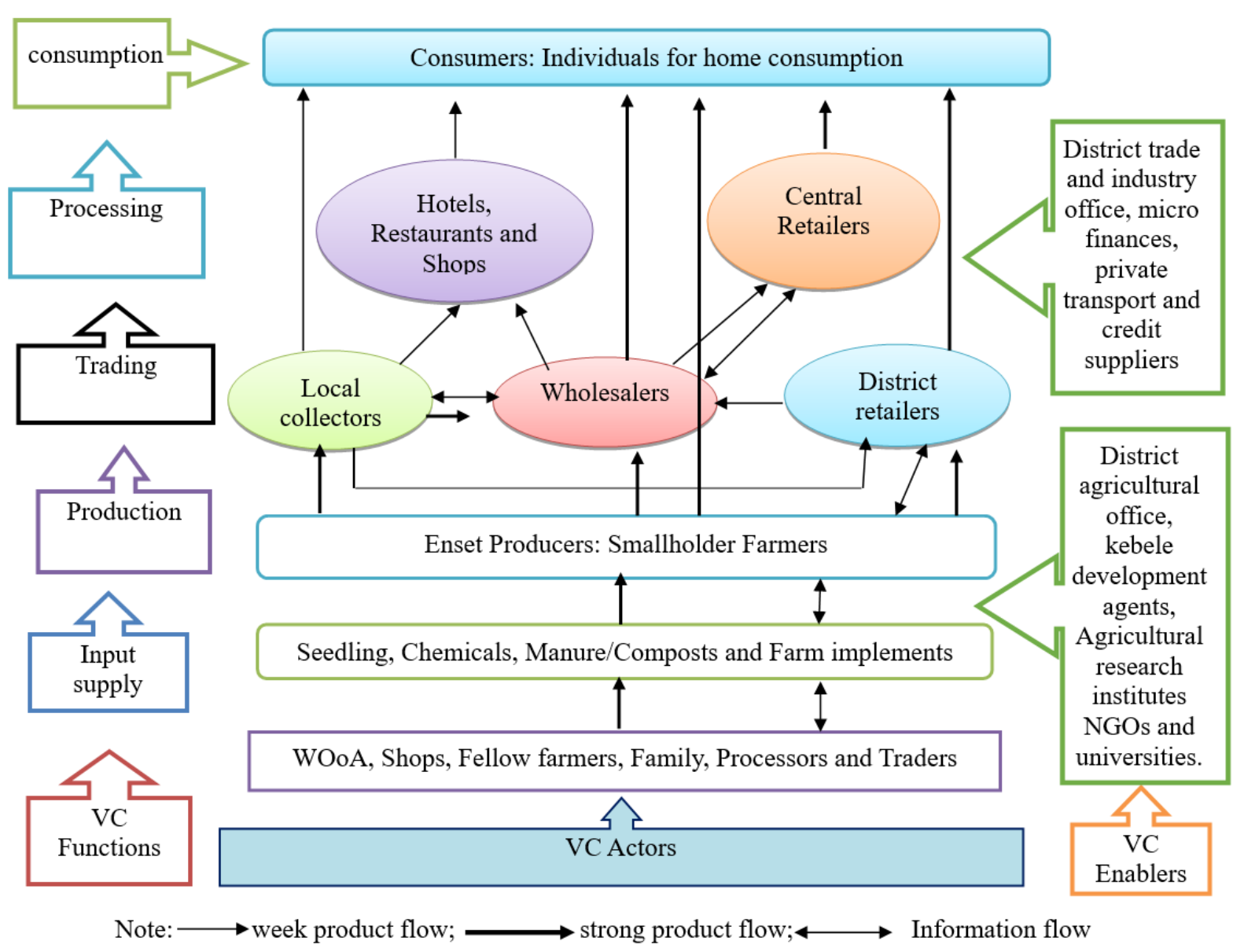

Figure 1: value chain map of enset product in the study districts

\section{Enset input suppliers}

Enset products value chain analysis starts at the input access level. Input supplies were not main activity in enset value chain. Inputs such as: animal manure, compost, variety, labor contribution, chemicals and farm implement which are supplied by district office of agriculture, research centers, neighbors, fellow farmers, other farmers and traders. From total sampled producers' largest proportion $(93.3 \%)$ used local varieties while $6 \%$ both improved and local varieties and $(0.7 \%)$ only used improved varieties of enset.

\section{Enset producers}

Producers perform most of the value chain functions starts from farm preparation on their farms to post harvest handling and marketing. The major value chain functions that enset producers perform include land preparation, growing, replanting, cutting, cleaning, storing, composting/manuring, protecting from weed, pest/disease, harvesting and post-harvest handling and marketing. The smallholder enset producers produce mainly for home consumption, animal feeding, marketing, construction. $82.7 \%$ of sampled respondents were producing enset by sole cropping and small proportion $17.3 \%$ were producing by inter cropping with others short cycled crops. Enset producers are not marketed enset products as first preferences like other crops because of information lack, seasonality of demand, absence of harvesting technologies, quality problem and odor of the products. According survey result, $42 \%$ of household got low yield because of bacteria wilt disease, poor quality productivity of the varieties and land shortage. Sampled enset producers average harvested enset two times in a year was 11.37 enset plants and got average $28.03 \mathrm{~kg}$ of kocho, $6.65 \mathrm{~kg}$ bulla and $0.74 \mathrm{~kg}$ of fiber from one enset plant. Market participant enset producers' volume supplied to the market on average $73.02 \mathrm{~kg}$ kocho, $64.97 \mathrm{~kg}$ of bulla and 8.67 $\mathrm{kg}$ of fiber in a year. Enset producers stored their enset products using ground burrow covered with enset life and plastic materials. From observation made during survey period, most producers sold their products in the nearby local and urban markets. The means of transportation varies among farmers but predominately producers use human back, pack animals and vehicles.

\section{Local collectors}

Local collectors are independent part time traders at primary markets who collect enset products at local market and transport enset products from smallholder farmers to nearby by urban market centers. Local collectors also go to the farmer's field, negotiate price, purchasing, repacking, cleaning, sorting and ultimately transport mostly kocho and bulla products to urban markets using pack animals and small trucks. Their main sale outlets are 
relatively wholesalers, retailers and consumers.

Wholesalers

Wholesalers are traders involved in buying enset products from producer and local collectors in large volume than any actors and supplying them to retailers and consumer. Wholesalers have no license to do enset products marketing in the study district. Wholesalers' traders mostly purchase in large amount from the districts, transport and sell the products to the major towns like Hossana, Wolkitie, Adama, Butajira and Addis Ababa. wholesalers have good storage, transportation and communication access than other actors.

\section{Retailers}

They are key traders in enset products value chain inside and outside the study districts. They are the final segment between producers and consumers. In the study districts there are two types of retailers, districts retailers and central retailers. District retailers are buying enset products either from farmers, local collectors' traders. While central (outside) retailers in major cities mostly they buy from wholesalers and sell to urban consumers. Mostly retailers buying enset products by considering color, texture, odor and moisture contain of the product. Consumers mostly buy enset products from retailers as they offer according to their needs and purchasing power.

\section{Processors}

Processing of enset products in the sense of value addition is not as such practiced in the study districts. Processing function is undertaken by cafes, hotels or restaurants in which case cooked enset products are sold to consumers. kocho and bulla are commonly consumed in the form of cooked meals in different traditional dishes. On the other hand, individual processors buy enset products directly from local collectors, wholesalers and retailers specially bulla and kocho, upgrading product means filtering, change to powder form and packing by plastic means of increasing utility then sell to hotel, consumer and organizations.

\section{Consumers}

Consumers are final purchasers of enset products mostly from producers and retailers for consumption purpose. Enset product consumers are individual households (rural and urban dwellers), hotels and institutions.

\section{Enablers and facilitator}

Facilitators and enablers include all chain-based actors providing support services or representing the shared interest of the value chain actors. The supporting function players for enset products value chain are those who are not directly related to the enset products value chain but provide different supports to the value chain actors. Support service functions are essential for value chain development and include sector specific input and equipment providers, financial services, extension service, and market information access and dissemination, technology suppliers, advisory service, etc. In the study areas, there are some institutions supporting the enset products value chain in one way or another. The most common support providers are district office of agriculture, district trade and market development office, kebele development agents, micro finance institutions, private transporters, research centers, NGOs and universities.

\subsection{Enset Products Marketing Channels and Margins \\ 3.2.1. Kocho marketing channels}

Smallholder farmers sell kocho product through different channels. Five marketing channels of kocho are identified in the study areas. It was estimated that 6,743 kilograms of kocho were supplied to market by sampled producers. Out of total 6,743 kilograms of kocho marketed by sampled farmers during survey year the highest $(40.86 \%)$ was marketed through channel I and lowest $(14.31 \%)$ was through channel III. The survey results revealed that consumers and district retailers were the dominants receivers of kocho with percentage share of $40.86 \%$ and $27.98 \%$, respectively. 


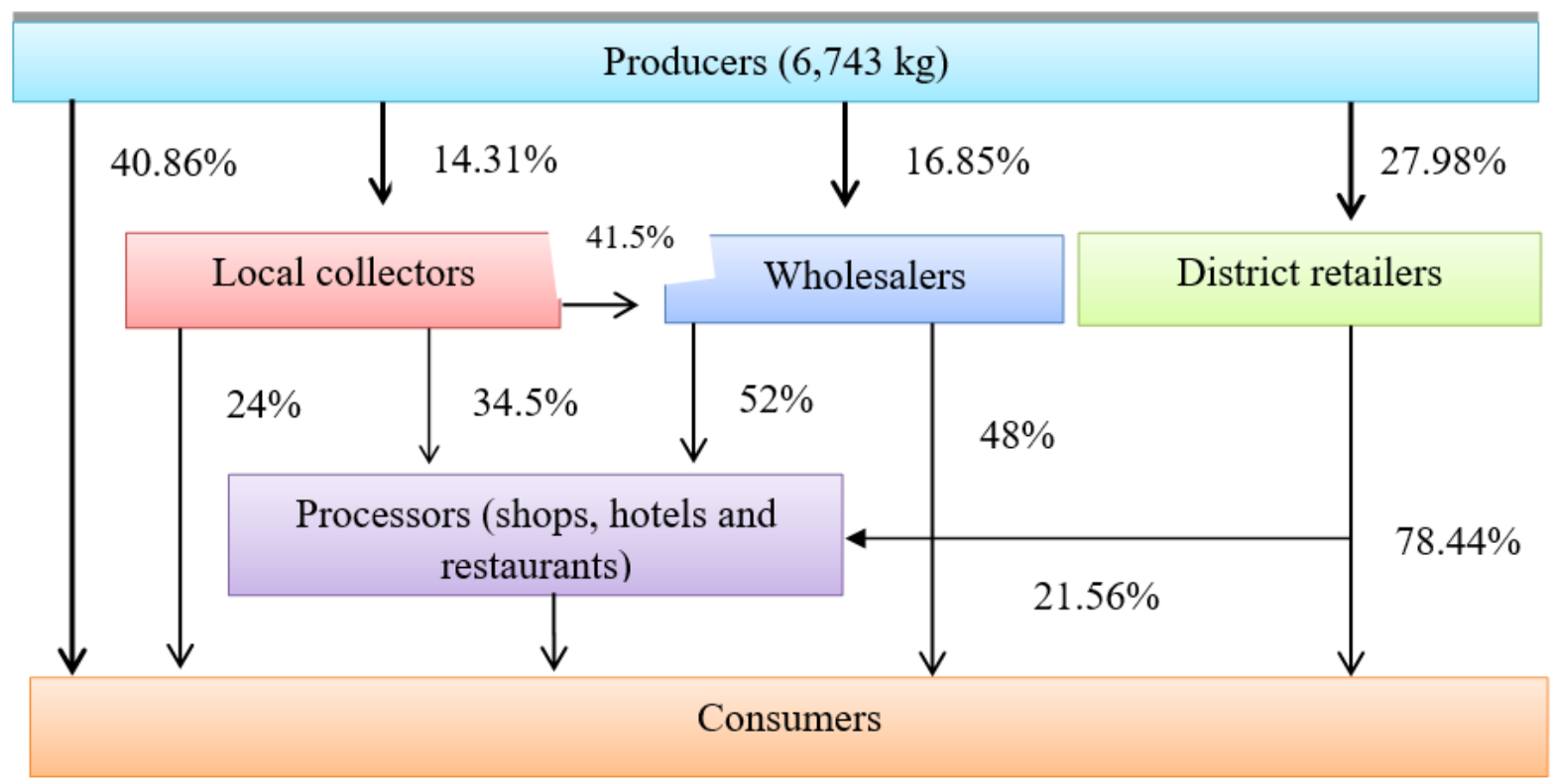

Figure 2: kocho marketing channels

\subsubsection{Kocho marketing margin analysis}

The survey results showed that kocho producers market profit was highest when they sell to consumers in channel I which is about $2.77 \mathrm{birr} / \mathrm{kg}$ and wholesalers in channel $\mathrm{V}$ which is about $2.52 \mathrm{birr} / \mathrm{kg}$ while took lowest market profit when they sell to local collectors which is about $2.02 \mathrm{birr} / \mathrm{kg}$ in channel III and IV. Producers share (GMMp) was highest (80\%) from the total consumers' price in channel-II and lowest in channel-III $(66.47 \%)$. The highest traders share (GMMt) from the total consumers' price was taken by wholesalers in channel - V which was $27.75 \%$. The lowest traders share from final consumers' price was taken by local collectors in channel III which was $14.45 \%$. The total gross marketing margin (TGMM) was lowest in channel- II and IV which was about $20 \%$ and $20.69 \%$, respectively and highest in channel- III was $33.53 \%$.

Table 2: Kocho marketing margin (birr $/ \mathrm{kg}$ )

\begin{tabular}{|c|c|c|c|c|c|c|}
\hline \multirow[t]{2}{*}{ Actors } & & \multicolumn{5}{|c|}{ Kocho marketing channels } \\
\hline & & I & II & III & IV & $\mathrm{V}$ \\
\hline \multirow[t]{6}{*}{ Producers } & Purchased price & & & & & \\
\hline & Production cost & 3.08 & 3.08 & 3.08 & 3.08 & 3.08 \\
\hline & Marketing cost & 0.65 & 0.65 & 0.65 & 0.65 & 0.65 \\
\hline & Selling price & 6.5 & 6 & 5.75 & 5.75 & 6.25 \\
\hline & Profit margin & 2.77 & 2.27 & 2.02 & 2.02 & 2.52 \\
\hline & GMMP (\%) & 100 & 80 & 66.47 & 79.31 & 72.25 \\
\hline Local & Purchased price & & & 5.75 & 5.75 & \\
\hline \multirow{4}{*}{ collectors } & Marketing cost & & & 0.7 & 0.7 & \\
\hline & Selling price & & & 7 & 7.25 & \\
\hline & Profit margin & & & 0.55 & 0.8 & \\
\hline & GMMLC (\%) & & & 14.45 & 20.69 & \\
\hline \multirow[t]{5}{*}{ Retailers } & Purchased price & & 6 & & & \\
\hline & marketing cost & & 0.65 & & & \\
\hline & Selling price & & 7.5 & & & \\
\hline & Profit margin & & 0.85 & & & \\
\hline & GMMR (\%) & & 20 & & & \\
\hline \multirow[t]{6}{*}{ Wholesalers } & Purchased price & & & 7 & & 6.25 \\
\hline & Marketing cost & & & 1 & & 1 \\
\hline & Selling price & & & 8.65 & & 8.65 \\
\hline & Profit margin & & & 0.65 & & 1.4 \\
\hline & GMMW (\%) & & & 19.08 & & 27.75 \\
\hline & TGMM (\%) & 0 & 20 & 33.53 & 20.69 & 27.75 \\
\hline
\end{tabular}

Source: Computed from own survey data, 2020 


\subsection{Determinants of Kocho Market Participation Decision and Market Supply}

Out of 150 total respondents interviewed and incorporated for analysis $61.33 \%$ were kocho market participants, while $38.67 \%$ were kocho market non - participants. The result of $1^{\text {st }}$ stage Double hurdle model estimation shows that the decision made by sampled households to marketed kocho or market participation decision is significantly and positively influenced by quantity of kocho produced, enset production experiences, market information access and credit access. The result of $2^{\text {nd }}$ stage Double hurdle model estimation implies that quantity of kocho marketed or volume supply to the market is positively and significantly affected by quantity of kocho produced, enset products marketing experiences and average kocho marketing price, whereas negatively affected by traveling distance to nearby market center.

Table 3: Model result on determinants of kocho market participation and market supply

\begin{tabular}{|c|c|c|c|c|c|c|c|}
\hline \multicolumn{5}{|c|}{ Kocho market participation decision } & \multicolumn{3}{|c|}{ Volume sales of kocho (kg) } \\
\hline Variables & Coef. & Std. Err & Z & $\mathrm{dy} / \mathrm{dx}$ & Coef. & Std. Err. & $\mathrm{Z}$ \\
\hline FAMs & -0.037 & 0.063 & -0.59 & -0.013 & -0.316 & 0.649 & -0.49 \\
\hline EDUs & -0.029 & 0.04 & -0.71 & -0.01 & 0.333 & 0.329 & 1.01 \\
\hline QKp & 0.002 & 0.001 & 1.66 & $0.001 *$ & $0.034 * * *$ & 0.008 & 4.06 \\
\hline LHs & 0.299 & 0.318 & 0.94 & 0.108 & -0.702 & 2.948 & -0.24 \\
\hline DNMc & -0.009 & 0.009 & -1.06 & -0.003 & $-0.171 *$ & 0.10 & -1.71 \\
\hline EPExp & 0.038 & 0.014 & 2.68 & $0.014 * * *$ & & & \\
\hline EXTa & 0.074 & 0.281 & 0.26 & 0.027 & -0.751 & 2.548 & -0.29 \\
\hline PREQbuy & & & & & -0.133 & 2.432 & -0.05 \\
\hline MRKTinfo & 0.588 & 0.276 & 2.13 & $0.210 * *$ & 0.166 & 2.819 & 0.06 \\
\hline CRDTa & 0.549 & 0.265 & 2.07 & $0.193 * *$ & -3.355 & 2.398 & -1.40 \\
\hline MRKTexp & & & & & $0.928 * * *$ & 0.32 & 2.90 \\
\hline AKMprice & & & & & $2.925 * * *$ & 0.888 & 3.30 \\
\hline _cons & $-1.499 *$ & 0.78 & -1.92 & & $26.258 * * *$ & 10.034 & 2.62 \\
\hline$\overline{\text { Sigma }}$ & & & & & $10.804 * * *$ & 0.797 & 13.56 \\
\hline \multicolumn{8}{|c|}{ Number of obs $=150 \quad$ Wald chi2 $(9)=64.98$} \\
\hline Pseudo R2 = & & Prob $>c$ & $=0.000$ & & $=208.66$ & $>\operatorname{chi} 2=$ & \\
\hline
\end{tabular}

Note: $* * *, * *$ and $*$ show the values statistically significant at $1 \%, 5 \%$ and $10 \%$ level respectively.

Enset production experience (EPExp): The expected influence of experience in the production of enset was positively taking the assumption that as smallholder farmers becoming more experienced in enset production they could acquire skills and hence produce much and develop skills to participate in the kocho market. This variable affected the probability of kocho market participants at $1 \%$ significant level. The marginal effect showed that sample household enset production experience increases by one year the probability of kocho market participation decision increased by $1.4 \%$ by holding other factors constant.

Quantity of kocho produced (QKp): The model result shows that kocho market participation decision and volume supplied to the market were significantly and positively affected by quantity kocho produced at $10 \%$ and $1 \%$ probability level, respectively. The positive coefficient indicates that a kilogram increase kocho produced increases the probability of kocho market participation decision and quantity supplied to the market. As quantity of kocho produced increased by one kilogram the probability of farmers' decision to market kocho increases by $0.1 \%$. It also shows that the higher the kocho produced, the higher the farmer is willing to supply more kocho output to the market. The coefficient for quantity kocho produced by sample households implied that an increase quantity of kocho produced by one kilogram resulted an increase the volume supplied by 0.034 kilogram, by keeping other factors constant.

Access to market information (MRKTinfo): Access to market information was found to have a positive and significant influenced on farmers' kocho market participation decision at 5\% level of significance. This indicates that farmers who had access to market information have better quantity of enset output sales. This is implying that farmer that had access to market information on price, buyers, production and marketing by different means of information like mobile, radio, traders, from other farmers and own observation would more quantity supplied and probability of kocho market participation decision increased by $2.1 \%$ than those who had not access to market information, by keeping all other factors constant. Good information can improve farmers' bargaining position, reduce search costs, and give them the choice to travel to farther markets if prices there are higher.

Credit access (CRDTa): The obtained result suggests that, those farmers who have access to credit service are more likely to produce significant amount of enset products than their counter parts, ceteris paribus. This highlights the importance of access to rural credit service in the quantity of production and supplied to market in the study areas. The marginal effect shows that those who have access to credit probability of kocho market participation decision increases by $19.3 \%$ more than those who do not have access to credit.

Distance to the nearest market center (DNMc): Traveling distance to the nearest urban market center by walking 
minutes of the sample household was negatively and significantly influenced the quantity of kocho sold in the market at $10 \%$ significance level. The result shows that as the distance to the nearby market center increases by one minute the quantity of kocho marketed decreases by 0.171 kilograms. This implies that the location of farmers in respect of potential markets is an important factor in encouraging farmers to increase their output sales. The closer the market, the lesser the transportation charges, reduced walking time, and reduced other marketing costs, better access to market information and facilities.

Enset products marketing experiences (MRKTexp): It has positive effect on kocho quantity supply to market with at $1 \%$ significance level. The survey results revealed that, if kocho producer more experienced on enset products marketing or enset products marketing experience increase by one year, the amount of kocho supplied to the market increases by 0.928 kilograms, by keeping other factors constant. This enables them to have better skills, better access to market information and create good linkage with kocho actors to supply more kocho to market.

Average kocho market price (AKMprice): Kocho market price during survey year has influence the households' quantity of kocho output marketed positively and significantly at $1 \%$ significance level. If they perceive previous kocho market price as good, they decide to produce more and sales or supply more amount of kocho than those who do not perceived the previous market price as such. This confirms that output price is an inducement for farm household to supply more marketed surplus. The result shows that if average kocho market price increase by one birr the quantity of kocho marketed increases by 2.925 kilograms, by keeping other factors constant. The finding is consistent with the expectation and is in line with the finding of Benjamin et al., (2014), revealed that output price is an incentive for farm households to participate more on supply market.

\subsection{Kocho Production and Marketing Constraints in the Study Districts}

As it is showed in below table. Lack of harvesting technology (76.7\%), lack of improved technology (62.7\%), lack of technical training (58.7\%), enset diseases (57.3\%) and bad weather condition(frost) (56\%) were the major production problems identified by sampled farmers in study districts and the remaining replied storage problems $(46.7 \%)$, low yield $(41.3 \%)$, lack of credit access $(38.7 \%)$, high input costs $(12 \%)$ and other problems $(6 \%)$ were insignificant problems by sampled respondent farmers in the study districts. Major marketing constraints in the study districts were low market price of the products $(65.5 \%)$, lack of demand $(64.7 \%)$, poor actor's linkage $(63.9 \%)$, market access problem (57.1\%), lack of market information (55.5\%), products price fluctuation.

Table 4: Kocho, bulla production and marketing constraints in the study areas

\begin{tabular}{llllll}
\hline Production constraints & Frequency & Percent & Marketing constraints & Frequency & Percent \\
\hline Lack of improved varieties & 94 & 62.7 & Low marketing price & 78 & 65.5 \\
Lack of harvesting technology & 115 & 76.7 & Shortage of supply & 45 & 37.8 \\
Enset diseases & 86 & 57.3 & Price fluctuation & 64 & 53.8 \\
Lack of technical training & 88 & 58.7 & Traders give same price & 47 & 39.5 \\
Lack of credit access & 58 & 38.7 & No market access & 68 & 57.1 \\
High input costs & 18 & 12 & Lack of market information & 66 & 55.5 \\
Low yield & 62 & 41.3 & Lack of demand & 77 & 64.7 \\
Bad weather condition (frost) & 84 & 56 & Poor actors' linkage & 76 & 63.9 \\
Storage problems & 70 & 46.7 & High transportation cost & 45 & 37.8 \\
Other problems & 9 & 6 & Poor road access & 37 & 31.1 \\
& & & Shortage of truck & 30 & 25.2
\end{tabular}

Source: Computed from own survey data, 2020

\subsection{Kocho Value Chain Opportunities in the Study Districts}

Adaptability and drought resistance of crop type (65\%), Good weather conditions (62\%), non - perishability of enset products $(60 \%)$, social coordination of community (work together) $(45.3 \%)$, farmers' indigenous skill and knowledge (41.3\%) and conducive environment (40\%) are major enset value chain opportunities in the study districts.

Table 5: kocho and bulla value chain opportunities in the study areas

\begin{tabular}{lll}
\hline Kocho and bulla value chain opportunities & Frequency & Percent \\
\hline Good weather conditions & 93 & 62 \\
Social coordination (work together) & 68 & 45.3 \\
farmers skill and knowledge & 62 & 41.3 \\
Adaptability and drought resistance of crop type & 98 & 65.3 \\
Non - perishability of enset products & 90 & 60 \\
Presence of infrastructure and market access & 27 & 18 \\
Other opportunities & 26 & 17.3 \\
\hline
\end{tabular}

Source: Computed from own survey data, 2020 


\section{CONCLUSION AND RECOMMENDATION}

\subsection{Conclusion}

About five different kocho market channels were identified with each channel having different marketing margin. The results showed that kocho producers market profit was highest when they sell to consumers in channel I which is about $2.77 \mathrm{birr} / \mathrm{kg}$ and wholesalers in channel $\mathrm{V}$ which is about $2.52 \mathrm{birr} / \mathrm{kg}$ while took lowest market profit when they sell to local collectors which is about $2.02 \mathrm{birr} / \mathrm{kg}$ in channel III and IV. The total gross marketing margin (TGMM) was highest in channel- III which was about $33.53 \%$ and lowest in channel-II which was about $20 \%$. Producer's share (GMMp) is highest (80\%) from the total consumers' price in channel-II and lowest in channel-III (66.47\%) because of the involvement of the number of actors in this channel. It is observed that as the number of actors increases, the producers share from final consumers' price decreases. Highest traders share from final consumers' price (GMMt) was taken by wholesalers $(27.75 \%$ ) in channel V and lowest was taken by local collectors in channel III which was $14.45 \%$.

The result of double hurdle model revealed that, out of total 12 explanatory variables included in the model. Bulla market participation decision was significantly and positively affected by quantity of bulla produced, enset production experience and market information. Six variables were significantly and positively affected quantity of bulla sales education status, quantity of bulla produced, extension service access, preferred quality of the product by buyers, average bulla market price, market experience.

At farm level, the major production constraints are shortage of improved high yield varieties, lack of harvesting and processing technologies, enset diseases, lack of technical training, bad weather conditions like frost, low yield of the varieties, lack of credit access, lack of improved storage technologies, high cost of inputs, lack of availability of adequate pesticides/herbicides, harvesting and post- harvest handling activities and animal attacks. At marketing/trading stage, low market price of the products, lack of market demand, price fluctuation, market access problem, poor road and transport facility, poor market information, product quality problem, poor actors' linkage as the major problems of enset products marketing. The major production and marketing opportunities of enset in the study areas are good weather conditions, adaptability and drought resistance of the crop, nonperishability of enset products, social coordination or working together of the community, indigenous skills and knowledge of the farmers.

\subsection{Recommendations}

Weak market linkage/ segment enset producers with actors in the study areas. So, the district trade and industry office and any other concerned bodies should strength the linkage/interaction among value chain actors, there is a need to change the attitude of actors, by developing ground rules that will include the relationship between producers and traders.

In the study areas, farmers not took trainings about increasing production, marketing and diseases controlling system. On the contrary the demand of enset products within the country especially, in many large cities increasing. So, the farmers need intensive training how to develop their production, enest products market linkage in line with facilitating marketing, enset diseases controlling mechanism and value addition knowledge also important.

Lack of high yield improved enset varieties like other crop commodities in the study areas. The role of research institutes and universities are crucial in identifying high yielding and disease resistant varieties to improve production and productivity of enset.

Enset products value adding activities in the study areas was poor. So, respective concerned bodies should capacitate enset producers and traders on processing and packaging enset products to improve income from the products.

Enset diseases like bacterial welt and leaf rust are barriers in the study areas. Due to, the presence of enset disease production yield of the commodity reduced and reduced market participation of the producers. In order to avoid the reduction of yield production and increase market participation of the farmer, awareness creation for integrated disease management should be done and crop protection services through availing chemicals for enset bacterial welt required to preventing disease.

No enset harvesting and processing technologies in the areas. Farmers used traditional way of enset harvesting and processing with high labor-intensive materials. So, the government should access enset harvesting and processing technologies to reduced farmers labour cost, to improve the quality of the products and to save working time.

\section{REFERENCE}

Abebe, U. and Paul, J. 2015. Enset value chain analysis; The case of Dire Enchini woreda, Oromia regional state, Ethiopia. Journal of Research in Computer Application and Management. 3(2): 7-14.

Ashenafi, C., Tadesse, K, and Girma, G. 2017. Value chain analysis of warqe food Products in Ethiopia. International Journal of Managing Value and Supply Chains, 8(1): 23-42 Doi: 10.5121/ijmvsc.2017.8102

Awiersum, T. and Bongers, F. 2010. Spatial and temporal variation in crop diversity in agroforestry home gardens 
of southern Ethiopia. Agrofor syst.78:309-322. Journal of Ethnobiology and Ethno medicine. 18to the School of Graduate Studies in Addis Ababa University in Partial. Link: https://bit.ly/313Zsb6

Belachew, G., Aklilu, A., Bewuketu, H., Habtamu, K. 2017. Indigenous Knowledge of Enset (Ensete ventricosum (Welw.) Cheesman) Cultivation and Management Practice by Shekicho People, Southwest Ethiopia, Journal of Plant Sciences. 5(1): 6-18. Doi: 10.11648/j.jps.20170501.12.

Benjamin, A., Yaw Bonsu, O. and Seini, W. 2014. Market Participation of Smallholder Maize Farmers in the Upper West Region of Ghana. African Journal of Agricultural Research. 9(31): 2427-2435.

Borrell, S., Biswas, K., Goodwin, M., Blomme, G., Schwarzacher, T., Heslop-Harrison, S., Wendawek, M., Berhanu, A., Kallow, S., Janssens, S., Molla, L., Davis, P., Woldeyes, F., Willis, K., Demissew, S. and Wilkin, P. 2019. Enset in Ethiopia: a poorly characterized but resilient starch staple. Annals of Botany, Vol. 123(5):747-766. https://doi.org/10.1093/aob/mcy214.

Brandt, S., Spring, A., Hiebsch, C., McCabe, J., Tabogie, E., Wolde - Michael, G., Tesfaye, S. 1997. The "Tree Against Hunger": Enset - based agricultural system in Ethiopia. American Association for the Advancement of Science, 56. http://users.clas.ufl.edu/aspring/publications/enset.pdf

Carol, N., Maeve, H. and Alan, M. 2003. A double-hurdle model of Irish household expenditure on prepared meals. Applied Economics. Vol.35(9). 1053-1061, DOI: 10.1080/0003684032000079170.

CDOoA. 2020. Report on socio economic and background information of the district, Cheha District Office of Agriculture, Ethiopia. Unpublished documents.

Cragg, J. 1971. Some Statistical Models for Limited Dependent Variables with Application to the Demand for Durable Goods, Econometrica. 39: 829-844. https://doi.org/10.2307/1909582

Ghorbani, M. 2008. The Efficiency of Saffron"s Marketing Channel in Iran. World Applied Sciences Journal, 4(4): 523-527.

Haile, A., Megerssa, B. and Negash, R. 2020. Enset (EnseteVentricosoum) Value Chain in Dawuro Zone, Southern Ethiopia. Int J AgricSc Food Technol. 6(2): 126-150. Doi: 10.17352/2455-815X.000065

MADOoA. 2020. Report on socio economic profile and background information of the district, Mirab Azernet District Office of Agriculture, Ethiopia. Office data.

Mendoza, G. 1995. A Primer on Marketing Channels and Margins. Lyme Rimer Publishers Inc., USA. 425 p.

Negash, A., Niehof, A. 2004. The significance of enset culture and biodiversity for rural household food and livelihood security in southwestern Ethiopia. Agriculture and Human Values. 21: 61-71. https://doi.org/10.1023/B:AHUM.0000014023.30611.ad.

Nuri, L., Jema, H., Endrias, G. and Lemma, Z. 2016. Determinants of status and extent of market participation among kocho Producers in Hadiya Zone, Southern Ethiopia. Int. J. Agril. Res. Rev. 4(2): 476- 485.

Olango, T., Tesfaye, B., Pe, M. 2014. Indigenous knowledge, use and on-farm management of enset (Ensete ventricosum (Welw.) Cheesman) diversity in Wolaita, Southern Ethiopia. Journal of Ethnobiology and Ethnomedicine. https://doi.org/10.1186/1746-4269-10-41.

Sahle, M., Yeshitela, K., \& Saito, O. 2018. Mapping the supply and demand of Enset crop to improve food security in Southern Ethiopia. Agronomy for Sustainable Development. 38(1), 7. https://doi.org/10.1007/s13593-0170484-0.

Seyoum, C., Lemma, T., and Karippai, R. 2011. Factors determining the degree of commercialization of smallholder agriculture: the case of potato growers in Kombolcha District, East Hararghe, Ethiopia. Journal of Agriculture and Development (JAD). 2(1): 18-36. Addis Ababa: St. Mary's University.

Shumbulo, A., Gecho, Y. and Tora, M. 2012. Diversity, challenges and potentials of enset (ensete ventricosum) production: in case of Offa Woreda, Wolaita zone, southern Ethiopia. food science and quality management.7: 24-32. www.iiste.org. ISSN 2225-0557 (Online).

Smith, D. 1992. Costs and Returns in Agricultural Marketing. Marketing and Agribusiness Development Paper. Department of Political Economy, University of Glasgow. Glasgow, Scotland. 67p.

Yamane, T. 1967. Statistics: An Introductory Analysis, 2nd Edition, New York: Harper and Row.

Yilma, T. 2001. Coffee-Enset-Livestock Interaction for sustainable livelihood in the Sidama area of Southern Ethiopia. International Conference on African Development Archives.39. https://scholarworks.wmich.edu/africancenter_icad_archive/39.

Zerfu, A., Gebre, S., Berecha, G. and Getahun, K. 2018. Assessment of spatial distribution of enset plant diversity and enset bacteria wilt using geostatistical techniques in Yem special district, Southern Ethiopia. Environmental Systems Research. 7(1), 23. https://doi.org/10.1186/s40068-018-0126-9. 